\title{
ResearchArticle
}

\section{Estimation of variability and genetic parameters for kernel quality traits (protein and oil content) in the seedling raised natural walnut (Juglans regia L.) population in the Kashmir valley}

IMTIYAZ AHMAD LONE

\begin{abstract}
SUMMARY
The present investigation on estimation of variability and genetic parameters for kernel quality traits (protein and oil content) in the seedling raised natural walnut (Juglans regia L.) population in the Kashmir valley was carried out in order to document the available genetic variability in walnut germplasm and to select elite walnut genotypes possessing superior attributes and quality traits. During the survey, data were recorded on one hundred fifty two (152) walnut trees growing in different areas of Kashmir valley. Remarkable variability were observed in seedling walnut trees for different morphological, nut and kernel characters. Similarly, variations were also reported for other characters viz., tree vigour, growth habit, branching habit, leaflet shape, shoot colour, nut shape, shell texture, shell colour, shell seal, shell strength, shell integrity, kernel shrivel and kernel colour. Studies that the oil content of kernels had a population mean of 62.102 per cent with a range of 50.22-70.00 per cent. Maximum kernel oil content (70\%) was found in the walnut selection WS-114 and minimum (50.22\%) in the WS-150. Analysis of variance revealed a phenotypic variance of 29.027 as compared to genotypic variance of 8.546 with environmental variance being 20.48. Based on the estimation of components of variance, the phenotypic and genotypic co-efficients of variation were 8.67 and 4.70 per cent, respectively. Heritability (broad sense) was 47.43 per cent and the expected genetic gain as only 5.261 ( $\%$ of the mean).
\end{abstract}

Key Words : Walnut, Kernel characteritcies, Oilcontent, Protines

How to cite this article : Lone, Imtiyaz Ahmad (2017). Estimation of variability and genetic parameters for kernel quality traits (protein and oil content) in the seedling raised natural walnut (Juglans regia L.) population in the Kashmir valley. Internat. J. Plant Sci., 12 (2): 258-261, DOI: 10.15740/HAS/IJPS/12.2/258-261.

Article chronicle : Received : 10.05.2017; Revised : 04.06.2017; Accepted : 20.06.2017 